\title{
Migration Behavior within Socio-Cultural and Demographic Context: A Case Study of Faisalabad City, Pakistan

\author{
Muhammad Iqbal Zafar
}

Dean, Faculty of Social Sciences, University of Agriculture, Faisalabad, Pakistan

Sadaf Siddique

Department of Rural Sociology, University of Agriculture, Faisalabad, Pakistan

Muhammad Usman Zafar

Lecturer, Department of Business Administration, G. C. University Faisalabad, Pakistan

Muhammad Asim

Corresponding Email: masim202@gmail.com Department of Sociology, G. C. University Faisalabad, Pakistan

Zahira Batool

Department of Rural Sociology, University of Agriculture, Faisalabad, Pakistan

Doi:10.5901/ajis.2013.v2n2p29

\section{Abstract}

\begin{abstract}
Migration is universal phenomena and people move from rural areas to urban areas, from developing countries to developed countries and from societies with stagnant economic conditions to societies for searching batter socio-economic status to address their economic and social needs. The nature of migration may be permanent or temporary depending on the nature and extent of needs of the migrants. Migration can effect positively or negatively the individuals, communities and nations directly and indirectly while migration from rural areas to urban areas in developing societies like Pakistan have more social, economic and cultural implications for the urban areas. The present study was designed to examine the various socio economic and demographic factors affecting migration behavior of the people. The respondents of the study were the male heads of families of the migrants. A sample of 120 respondents was taken from district Faisalabad. Interviewing, schedule was prepared in the light of research objectives for data collection. Descriptive analysis reflects that better education, better employment, better living status, better health facilities as reported by $80 \%, 78.3 \%, 75 \%$, and $72.5 \%$ of the respondents respectively were the causes of their migration to the urban areas. The researcher also found that some cultural factors i.e. family conflict, family disorganization, and rough and tough control of family elders had positively impact on migration to urban area. The motivation of relatives and friends who lived in urban areas played a vital role in making final decision to migrate.
\end{abstract}

Keywords: Migration, Socio, economic, cultural factors, descriptive analysis

\section{Introduction}

People tend to move from one area whether rural or urban, developing country or developed country keeping in view multi-dimensional aspects, motives or causes. The decision to move is based on certain felt deprivations, stress, constraints, aspirations, motivation at the place of origin. Deprivations are felt by collectively or individuals when the immediate needs are not fulfilled by the existing conditions within a community (Haq, 1974). Migration is movement of individuals from one geographical area to another. It may be permanent or temporary nature of migration. There must be a reason or a reason of migration-either something is chasing the people off from their gift location or there is an 
attraction to where they are going to. (Makama, 2010) identified number of reasons why people move from one space to another are natural disasters, physical conditions, insecurity, economic opportunities, change in standing and differences in social amenities. Today, urban-rural migration is one of the most important modes of migration which exist in the society. Until recently, researchers have not paid much attention to the rural urban drift. Studies by (William, 1970) reveal that some factors could send one off a place, which might be due to crisis, old age, transfer, retirement and invasion of pests and diseases. Also some social factors may evolve to make people migrate to rural areas. Studies by ljere (1994) show that factors influencing people to migrate to rural areas might be as a result of city congestion, traffic, dams, sanitation problems, increasing urban unemployment, increased crime rate and housing problem. Overtime, the most frequently heard explanation for migration has been the so called "push-pull theory", which depicts that some people move because they are pushed out of their former location, whereas others move because they have been pulled or attracted to some place elsewhere. However, in most developing countries, employment in the agricultural sector is decreasing. Many rural areas are undergoing a process of "de-agrarianization", with younger workers seeking to move out of agriculture because of lack of jobs, low incomes and agro-climatic constraints. Increasing numbers of rural people are working in non-agricultural activities in or outside their place of origin in order to diversify their income and reduce risk. In the late 1990s, rural non-farm activities accounted for 42 per cent of rural households' income in Africa1, 40 per cent in Latin America2 and 32 per cent in Asia (Reardon et al. 1998).

Pakistan is country with 180 million and population growth is also high as compared to many developing countries. More than 68 percent population lives in rural areas in extreme poor socio-economic conditions. As different studies indicate that more than one third of rural population is below the poverty line along with further division of land into the growing families. People find no way other than migration to urban areas to address their socio-economic and health needs. In Pakistan migration has always been an important phenomenon. After independence in 1947, a population exchange between India and Pakistan took on a scale never before recorded in human history, involving more than 14 million people (Arif and Hamid, 2009). Migration is one of the most important phenomena affecting economic, social, cultural, demographic and political setup of individuals, communities and nations. Although attention is currently focused on the impact of migration to cities, out migration can be equally important particularly if the social composition of in and out-migrant flow is very different. Differential migration reshaped the social structure of the cities in a few decades leading to economic and social problems in terms employment opportunities, health care, education, infrastructure and the provision of social facilities. The urban population of Pakistan at the time of independence 1947 was 5 million (15.4\%) that had increased to 23.84 million (28\%) in 1981 and further to 42.445 million (32.5\%) in 1998. During 1981 to 1998 , the total population increased by $55 \%$, whereas the urban and rural population increased by $60 \%$ and $40 \%$, respectively. However, during 2003, the rural and urban population was estimated to be 89.7 million (61\%) and 53.3 million (39\%), respectively (Government of Pakistan, 2002).

Pakistan is the most urbanized nation in South Asia with city dwellers making up $36 \%$ of its population, whil e the urbanization rate is $3 \%$ (Govt. of Pakistan, 2010).

\section{Methodology}

The study was focus on discussing the factors affecting rural to urban migration. The present study was planned to investigate the socio-economic factors affecting rural to urban migration in Faisalabad city. A sample of 120 respondents was selected systematically from Faisalabad city through multistage sampling technique. A cross-sectional survey was conducted in three randomly selected localities namely Al-Najaf colony, Samnabad and Mansurabad. 40 male household head were select through systematic randomly sampling technique from each locality.

\section{Result and Discussion}

Table 1. Distribution of the respondents according to their main purpose of migration.

\begin{tabular}{|l|c|c|c|c|c|c|}
\hline \multirow{2}{*}{$\begin{array}{c}\text { Main purpose of migration } \\
(\mathbf{n = 1 2 0})\end{array}$} & \multicolumn{2}{|c|}{ To a great extent } & \multicolumn{2}{c|}{ To some extent } & \multicolumn{2}{c|}{ Not at all } \\
\cline { 2 - 7 } & Freq. & \%age & Freq. & \%age & Freq. & \%age \\
\hline Education & 96 & 80.0 & 16 & 13.3 & 8 & 6.7 \\
\hline Employment & 94 & 78.3 & 22 & 18.3 & 4 & 3.3 \\
\hline Better living status & 90 & 75.0 & 22 & 18.3 & 8 & 6.7 \\
\hline Health facilities & 87 & 72.5 & 23 & 19.2 & 10 & 8.3 \\
\hline
\end{tabular}


Table 1 depicts that $88 \%$ of the respondents reported the education their purpose of migration 'to a great extent, 13.3 percent of them had 'to some extent' and 6.7 percent of them never mentioned that the education as a main purpose of migration. A majority 78.3 percent of the respondents reported the employment their purpose of migration 'to a great extent, 18.3 percent of them had 'to some extent' and 3.3 percent of them had not employment as a main purpose of migration. A majority 75.0 percent of the respondents reported the better living status their purpose of migration 'to a great extent', 18.3 percent of them had 'to some extent' and 6.7 percent of them had not 'better living status' as a main purpose of migration. A majority 72.5 percent of the respondents were migrated due to health facilities 'to a great extent' purpose of migration, 19.2 percent of them had 'to some extent' health facilities purpose of migration and 8.3 percent of them had not this purpose of migration. Only 4.0 percent of the respondents had any others purpose for migration. Similar results were found by Jason (2000); Kuhn (2002; Ahmad (2002); Saleem (2004); Hussain et al. (2004); Siddiqi (2004); Farooq et al. (2005). They found that majority of the people were migrated due to better income/job opportunities, education and better living status.

Table 2. Distribution of the respondents according to the reasons for moving from origin.

\begin{tabular}{|l|c|c|c|c|c|c|}
\hline \multirow{2}{*}{ Reasons $(\mathbf{n = 1 2 0 )}$} & \multicolumn{2}{|c|}{ Not at all } & \multicolumn{2}{c|}{ To some extent } & \multicolumn{2}{c|}{ To great extent } \\
\cline { 2 - 7 } & Freq. & $\%$ & Freq. & $\%$ & Freq. & $\%$ \\
\hline No job opportunities available in the origin & 20 & 16.7 & 31 & 25.8 & 69 & 57.5 \\
\hline Wages in the origin are poor & 7 & 5.8 & 42 & 35.0 & 71 & 59.2 \\
\hline Job opportunities are rare in the origin & 12 & 10.0 & 36 & 30.0 & 72 & 60.0 \\
\hline Bad living conditions in the origin & 25 & 20.8 & 40 & 33.3 & 55 & 45.8 \\
\hline Need more money & 6 & 5.0 & 45 & 37.5 & 69 & 57.5 \\
\hline Work in the origin is seasonal & 23 & 19.2 & 58 & 48.3 & 39 & 32.5 \\
\hline Work in the origin is temporary & 25 & 20.8 & 49 & 40.8 & 46 & 38.3 \\
\hline Do not own agriculture land to work in the field & 62 & 51.7 & 12 & 10.0 & 46 & 38.3 \\
\hline Work in the village "does not afford a mouth full of bread" & 57 & 47.5 & 20 & 16.7 & 43 & 35.8 \\
\hline Escape from family pressure and troubles & 34 & 28.3 & 31 & 25.8 & 55 & 45.8 \\
\hline Have no occupation (like craftsmen, etc.) & 57 & 47.5 & 36 & 30.0 & 27 & 22.5 \\
\hline Cannot work in the agriculture field & 44 & 36.7 & 27 & 22.5 & 49 & 40.8 \\
\hline Absence of education facilities & 26 & 21.7 & 29 & 24.2 & 64 & 53.3 \\
\hline Family disorganization & 41 & 34.2 & 30 & 25.0 & 49 & 40.8 \\
\hline Tight control of family & 41 & 34.2 & 15 & 12.5 & 64 & 53.3 \\
\hline Poor health institutions & 5 & 4.2 & 29 & 24.2 & 86 & 71.7 \\
\hline Polluted environment & 85 & 70.8 & 21 & 17.5 & 14 & 11.7 \\
\hline
\end{tabular}

Table 2 depicts that majority i.e. 57.5 percent of the respondents were agreed to great extent and about one-fifth i.e. 25.8 percent of them were agreed to some extent with the opinion "no job opportunities available in the origin" and 16.7 percent of them were not at all about this opinion. These findings are in line with Kim (1982). He found that a major proportion of the people migrated due to the less job opportunities in rural areas. A majority i.e. 59.2 percent of the respondents was agreed to great extent and 35.0 percent of them were agreed to some extent with the opinion "wages in the origin are poor" and only 5.8 percent of them were not at all about this opinion. A majority i.e. 60.0 percent, of respondents was agreed to great extent and 30.0 percent of them were agreed to some extent with the opinion "job opportunities are rare in the origin" and remaining 10.0 percent of them were not at all about this opinion. A major proportion i.e. 45.8 percent of the respondents were agreed to great extent and 33.3 percent of them were agreed to some extent with the opinion "bad living conditions in the origin" is a cause of their migration and 20.8 percent of them were not at all about this opinion. A major proportion i.e. 57.5 percent of the respondents were agreed to great extent and 37.5 percent of them were agreed to some extent with the opinion "need more money" is a reason of their migration and 5.0 percent of them were not at all about this opinion. About one-third of the respondents i.e. 32.5 percent were agreed to great extent and 48.3 percent of them were agreed to some extent with the opinion "work in the origin is seasonal" is a reason of their migration and 19.2 percent of them were not at all about this opinion.

About 38.3 percent of the respondents were agreed to great extent and 40.8 percent of them were agreed to some extent with the opinion "work in the origin is temporary" so they were migrated and 20.8 percent of them were not at all about this opinion. About 38.3 percent of the respondents were agreed to great extent and 10.0 percent of them were 
agreed to some extent with the opinion "Do not own agriculture land to work in the field" so they were migrated and 51.7 percent of them were not at all about this opinion. A one-third i.e. 35.8 percent of the respondents were agreed to great extent and 16.7 percent of them were agreed to some extent with the opinion "Work in the village "does not afford a mouth full of bread" so they moved from their origin and 47.5 percent of them were not at all about this opinion. About 45.8 percent of the respondents were agreed to a great extent and 25.8 percent of them were agreed to some extent with the opinion "Escape from family pressure and troubles" so they moved from their origin and 28.3 percent of them were not at all about this opinion. About 22.5 percent of the respondents were agreed to great extent and 30.0 percent of them were agreed to some extent with the opinion "Have no occupation (like craftsmen, etc.)" so they moved from their origin and 47.5 percent of them were not at all about this opinion. Almost 41 percent of the respondents were agreed to great extent and 22.5 percent of them were agreed to some extent with the opinion "Cannot work in the agriculture field" so they moved from their origin and 36.7 percent of them were not at all about this opinion. A majority i.e. 53.3 percent of the respondents was agreed to great extent and 22.5 percent of them were agreed to some extent with the opinion "Absence of education facilities" is a cause of moved from their origin and 21.7 percent of them were not at all about this opinion. About 40.8 percent of the respondents were agreed to great extent and 25.0 percent of them were agreed to some extent with the opinion "family disorganization" is a cause of moved from their origin and 34.2 percent of them were not at all about this opinion. A majority i.e., 53.3 percent of the respondents was agreed to great extent and 12.5 percent of them were agreed to some extent with the opinion "tight control of family" is a cause of moved from their origin and 34.2 percent of them were not at all about this opinion. A large majority i.e. 71.7 percent of the respondents was agreed to great extent and 24.2 percent of them were agreed to some extent with the opinion "poor health institution" is a cause of moved from their origin and only 4.2 percent of them were not at all about this opinion. About 11.7 percent of the respondents were agreed to great extent and 17.5 percent of them were agreed to some extent with the opinion "polluted environment" is a cause of moved from their origin and about 70.8 percent of them were not at all about this opinion. Similar results were found by Haq (1974). It was assumed that when opportunities like good jobs, educational and physical facilities and civic amenities were short in supply in the community, certain members of the community conceive the idea of moving out of it and going to different place where they could find adequate facilities and opportunities to raise their living standard.

Table 3: Distribution of the respondents according to the selection of destination

\begin{tabular}{|l|c|c|c|c|c|c|}
\hline \multirow{2}{*}{ Reasons $\mathrm{n}=\mathbf{1 2 0}$} & \multicolumn{2}{|c|}{ Not at all } & \multicolumn{2}{c|}{ To some extent } & \multicolumn{2}{c|}{ To great extent } \\
\cline { 2 - 7 } & Freq. & $\%$ & Freq. & $\%$ & Freq. & $\%$ \\
\hline Better economic opportunities & 7 & 5.8 & 14 & 11.7 & 99 & 82.5 \\
\hline High paying jobs & 13 & 10.8 & 11 & 9.2 & 96 & 80.0 \\
\hline Better education institutions & 0 & 0.0 & 24 & 20.0 & 96 & 80.0 \\
\hline Better health institutions & 13 & 10.8 & 17 & 14.2 & 90 & 75.0 \\
\hline Better transport facilities & 22 & 18.3 & 14 & 11.7 & 84 & 70.0 \\
\hline Better housing facilities & 20 & 16.7 & 27 & 22.5 & 73 & 60.8 \\
\hline Public entertainment & 17 & 14.2 & 38 & 31.7 & 65 & 54.2 \\
\hline
\end{tabular}

Table 3 indicates that the reasons of selection of destination. A huge majority i.e. 82.5 percent was agreed to a great extent and 11.7 percent of them were agreed to some extent with the opinion "better economic opportunities" is a reason of the selection of destination and only 5.8 percent were not at all about this opinion. A vast majority i.e. 80.0 percent was agreed to great extent and 9.2 percent of them were agreed to some extent with the opinion "high paying jobs" is a reason of the selection of this destination and 10.8 percent were not at all about this opinion. A large majority i.e. 80.0 percent were agreed to great extent and 20.0 percent of them were agreed to some extent with the opinion "better education institutions" is a reason of the selection of this destination. A majority i.e. 75.0 percent were agreed to great extent and 14.2 percent of them were agreed to some extent with the opinion "better health institutions" is a reason of the selection of this destination and only 10.8 percent were not at all about this opinion. A significant majority i.e. 70.0 percent was agreed to a great extent and 11.7 percent of them were agreed to some extent with the opinion "better transport institutions" is a reason of the selection of this destination and only 18.3 percent were not at all about this opinion. Almost 61.0 percent of the respondents were agreed to great extent and 22.5 percent of them were agreed to some extent with the opinion "better housing facilities" is a cause of the selection of this destination and 16.7 percent were not at all about this opinion. More than a half i.e., 54.2 percent was agreed to a great extent and 31.7 percent of them were agreed to 
some extent with the opinion "public entertainment" opportunities is a cause of the selection of this destination and 14.2 percent were not at all about this opinion. Above results supported to Jason (2000); Kuhn (2002; Ahmad (2002); Wakabayashi (2002); Saleem (2004); Hussain et al. (2004); Siddiqi (2004); Farooq et al. (2005). They found that majority of the migrants got better income/job opportunities, better education and living status after migration.

Table 4: Relationship between different independents and dependent variables (Satisfaction with the decision of migration)

\begin{tabular}{|l|c|c|c|c|c|}
\hline Independent variables & Chi-square & d.f. & P-value & Gamma & P-value \\
\hline Age of the respondents & 6.78 & 4 & $.148^{\mathrm{NS}}$ & -.136 & $.339 \mathrm{NS}$ \\
\hline Education & 21.75 & 8 & $.005^{\star \star}$ & .327 & $.006^{\star \star}$ \\
\hline Type of family & .746 & 2 & $.689^{\mathrm{NS}}$ & -.066 & $.725^{\mathrm{NS}}$ \\
\hline Income (after migration) & 11.19 & 4 & $.024^{\star}$ & .344 & $.05^{\star}$ \\
\hline Age at migration & 24.67 & 4 & $.000^{\star *}$ & .280 & $.05^{\star}$ \\
\hline No. of rooms & 21.18 & 12 & $.048^{\star}$ & .242 & $.034^{\star}$ \\
\hline Nature of job & 8.44 & 2 & $.015^{\star}$ & .553 & $.015^{\star}$ \\
\hline Health facilities & 20.65 & 4 & $.000^{\star}$ & .341 & .002 \\
\hline
\end{tabular}

${ }^{*}=$ Significant,

${ }^{* *}=$ Highly Significant,

NS = Non-Significant

1. Age of respondents has not been emerged as significant variable in affecting satisfaction with decision to migrate. The Chi-Square value which is 6.78 insignificant at 5 percent level of significance is the reflection whatever the age respondents whether younger or older they were equally satisfied with decision to migrate. Gamma value which is -.136 non-significant at 5 percent level supports the findings of insignificant relationship between independent and dependent variable emerged through Chi-Square value. So the hypothesis "age of the respondents is associated with the satisfaction level of the respondents with the decision to migrate" is rejected.

2. Education is universally established as an important factor to shape human behavior and attitude toward multidimensional human activities. Chi-square value (21.75) shows a highly-significant association between education of the respondents and their satisfaction with the decision of migration. Gamma value (3.27) shows a strong positive relationship between the variables. It means that respondents with more education were more satisfied with their decision migrate to urban area as compared to respondents with less education or illiterate. So the hypothesis "education of the respondents is associated with the satisfaction level of the respondents about the decision to migrate" is accepted. It support the idea that educated people understand the urban lifestyle and adjust in that environment may be reasons for their higher satisfaction as compared to illiterate people.

3. Type of family whether nuclear or joint may affects the satisfaction level regarding the decision to migrate. Chi-square value (0.746) shows a non-significant association between type of family of the respondents and their satisfaction with the decision of migration. Gamma value also shows a non significant relationship between the variables. It can be said whether the respondents live nuclear set up or in joint or extended family system they had the same level of satisfaction with decision to migrate. So the hypothesis "family structure of the respondents is associated with the satisfaction level of the respondents about the decision to migrate" is rejected.

4. Income of people as indicated in many studies on migration is an important predictor to shape their attitude whether they migrate or not. If they able to earn good amount of income at the place of destination they will be satisfied with their decision of migration. This relationship of income and satisfaction with decision to migrate has been studied. Chi-square value (11.19) shows a significant association between income (after migration) and respondents' satisfaction with the decision of migration. Gamma value shows a strong positive relationship between the variables. It means respondents with high income of the respondents had more satisfaction as compared to low income respondents. So the hypothesis "Income of the respondents is associated with satisfaction level with their decision to migrate to urban areas." is accepted.

5. Age of respondents when a person analyzes information on migration is vitally important. It has been argued that the younger people likely to move more as compared to older people. The association of age with satisfaction level emerged in this study. Chi-square value (24.67) shows a highly significant association 
between age at migration of the migrants with satisfaction level regarding decision of migration. Gamma value shows a strong positive relationship between the variables. It can be said that respondents who were young at time of migration were more satisfied with their decision to migrate to urban areas as compared to older respondents. This relationship logical due the reasons that younger people likely to more education, more strength and more time to make their life comfortable and adjust in urban life as compared to older people. So the hypothesis "Age at migration of the respondents is associated with satisfaction level with their decision to migrate to urban areas." is accepted.

6. The similar relationship which links with house the number of rooms is associated with the satisfaction of respondents with decision to migrate. The Chi-Square and Gama values do support this relationship. So the hypothesis "Number of rooms in house of the respondents is associated with satisfaction level with their decision to migrate to urban areas" is accepted.

7. Nature of job does influence the people satisfaction with their decision to migrate. Undoubtedly people with better or white color job likely to more happy or satisfied with their migration as compared people with blue color job. Chi-square value (8.44) shows a significant association between nature of job of the respondents and satisfaction with the decision of migration. Gamma value shows a positive relationship between the variables. So the hypothesis "Nature of job of the respondents is associated with satisfaction level with their decision to migrate to urban areas." is accepted.

8. As advocated in many studies on migration the significance of health facilities as a correlate of migration. The health facilities are major problem in developing countries the people likely to face those who live in rural areas. The association between health facilities and the respondents' satisfaction with migration is emerged in this research. Chi-square value (20.65) shows a highly significant association between health facilities and respondents satisfaction with the decision of migration. Gamma value shows a positive and significant relationship between the variables at 5 percent level of significance. So the hypothesis "Health facilities available to the respondents are associated with satisfaction level with their decision to migrate to urban areas" is accepted.

\section{Conclusion}

Descriptive analysis demonstrates that insufficient, inappropriate educational, health, recreational facilities, poor infrastructure and stagnant and limited economic opportunities in rural areas are the prime factors which motivate the individuals and families to migrate to the urban areas. With increasing migration from rural to urban areas, the multidimensional problems such sanitation, environmental pollution, overcrowded housing, congested traffic, overpopulation, road accidents and crimes are increasing. Govt. should provide to rural areas better economic opportunities, better sanitation facilities, better health facilities better educational facilities, better infrastructure, better transportation, promotion of cottage industry, and establishment of small industry near the villages to divert the major flow of people from rural areas to urban areas.

\section{References}

Ahmad, N. 2002. Effects of socio-economics and cultural factors on migration behaviour: A case study of Lahore City. Deptt. of Sociology, University of Agriculture, Faisalabad.

Arif, G.M. and S. Hamid. 2009. Urbanization, City Growth and Quality of Life in Pakistan. European Journal of Social Sciences. (10):2

Govt. of Pakistan, 2010. Economic Survey of Pakistan. Ministry of Finance, Govt. of Pakistan, Islamabad. Pakistan.

Farooq, M., A. Mateen and M.A. Cheema. 2005. Determinants of Migration in Punjab, Pakistan: A Case Study of Faisalabad Metropolitan. J. Agri. Soc. Sci., 1(3): 280-282.

Haq, A., 1974. Theoretical consideration for studying socio-psychological factors in migration. The Pakistan Rev., XIII: 353-60

Hussain, S., B.N. Siddiqui, M.Zakaria and Y. Hassan, 2004. A Sociological Study of Factors Responsible for Migration: A Case Study of Faisalabad City (Pakistan). Int. J. Agri. Biol. 6(4).

ljere, N.J. 1994. Gender and Rural-Urban Migration in the Ecuadorian Sierra. Columbia University Press, Columbia.

Jason, S. 2000. Why People Move: Exploring the March 2000 Current Population Survey. U.S. Department of Commerce Economics and Statistics Administration U.S. Census Bureau

Kim, Y. ( 1982) Regional Fertility Differentials in IIASA Nations, forthcoming. 
Kuhn, R.S. 2002. The Determinants of Family and Individual Migration: A Case-Study of Rural Bangladesh. Research Program on Population Processes POP2005-05 and Population Aging Center PAC2005-04

Makama, F. 2010. Factors Affecting Migration and Solutions to Rural-Urban Migration, Especially to Developing Nations. Ezani Articles. Available at: http://ezinearticles.com/?Factors-Affecting-Migration-and-Solutions-to-Rural-Urban-Migration,-Especially-toDeveloping-Nations\&id=5333792

Reardon, T., K. Stamoulis, M.E. Cruz, A. Balisacan, J. Berdegue and B. Banks. 1998. Rural non-farm income in developing countries. In FAO: the state of food and agriculture (FAO Agriculture Series, No. 31) Rome

Saleem, A. 2004. "Of migration" Mang Group of Newspapers September 06, 2004. Online available on: (http://www.jang.com.pk).

Siddique, M.W. 2004. Rural-urban migration (A case study of Lahore district). Higher Education Commission. University of the Punjab William, A.H. 1970. Population, Migration and Urbanization in Africa. Colombia University Press, Colombia. 
